\title{
Tanggung Jawab Perusahaan Asuransi Terhadap Tertanggung Dalam Penutupan Asuransinya Melalui Media Internet
}

\author{
Desni Raspita* \\ Fakultas Hukum Universitas Muhammadiyah Palembang \\ *Correspondence email: desniraspita3@gmail.com
}

\begin{abstract}
Abstrak. Dalam perkembangan zaman akan berpengaruh pada peradaban manusia yaitu dengan penemuan salah satu teknologi yaitu internet. Teknologi internet pada saat ini telah berkembang dengan pesat sehingga menjadi basis pada berbagai kehidupan manusia.Metode penelitian yang digunakan adalah penelitian hukum normatif.Tanggung jawab antara perusahaan asuransi (penanggung) terhadap tertanggung jika terjadi klaim kerugian dimana penutupan asuransinya melalui media internet, adalah sama halnya dengan tanggung jawab asuransi yang ditutup secara konvensional, dimana tanggung jawab perusahaan asuransi baik yang melalui internet maupun konvensional sudah ditegaskan dalam polis asuransi kerugian serta pengecualiannya yang telah disepakati oleh kedua belah pihak pada waktu penutupan perjanjian asuransi.
\end{abstract}

Kata Kunci: Asuransi; Internet; Teknologi

Abstract. In the times, it will affect human civilization, namely the discovery of one technology, namely the internet. Internet technology at this time has developed rapidly so that it becomes the basis for various human lives. The research method used is normative legal research. with insurance responsibilities that are closed conventionally, where the responsibilities of insurance companies both via the internet and conventional have been confirmed in the loss insurance policy and the exceptions that have been agreed upon by both parties at the time of closing the insurance agreement.

Keywords: Insurance; Internet; Technology

\section{PENDAHULUAN}

Dewasa ini, perekembangan sains dan teknologi semakin berkembang dengan pesat.Perkembangan sains dan teknologi modern tidak hanya menyangkut satu bidang kehidupan saja melainkan juga telah merambah kebidang kehidupan lainnya.Hal tersebut juga mempengaruhi kehidupan bermasyarakat. Masyarakat yang pada awalnya tidak mau tahu tentang teknologi, namun pada akhirnya harus berusaha menyesuaikan diri dengan perkembangan teknologi tersebut dan perkembangan zaman, jika tidak maka akan tertinggal informasi karena syarat untuk maju adalah harus mengikuti perkembangan zaman.

Dalam perkembangan zaman akan berpengaruh pada peradaban manusia yaitu dengan penemuan salah satu teknologi yaitu komputer. Komputer pada awalnya diciptakan untuk memberikan kemudahan pada manusia dalam melakukan berbagai perhitungan yang rumit akan menjadi mudah, menyimpan data lain dan sebagainya. Teknologi komputer pada saat ini telah berkembang dengan pesat sehingga menjadi basis pada berbagai kehidupan manusia.

Teknologi bukan lagi sebuah kata yang aneh ditelingan masyarakat, dahulu hanya orang-orang tertentu yang mempunyai askes di teknologi, contohnya alat telekomunikasi hanya dapat memiliki orang-orang kaya saja, tetapi sekarang sebagaian besar masyarakat sudah memiliki telepon baik portable maupun sellular.Demikian halnya dengan komputer, setiap orang dituntut untuk mengenal komputer baik untuk kepentingan pendidikan maupun untuk kepentingan usaha.

Pada saat ini perkembangan komputer sangatlah tinggi, setiap komputer dapat ditemui dalam setiap kehidupan, kegiatan pendidikan dapat dilakukan dengan mudah dengan menggunakan komputer.

Melalui sarana komputer manusia dapat berkomunikasi dengan cepat, juga dengan teknologi yang disebut surat elektronik (e-mail), berbagai informasi juga dapat disebar dan dicari melalui medium word wide web (www), bahkan transaksi bisnis juga dapat dilakuakn melelui internet. Bukan sekedar transaksi bisnis dalam jumlah yang kecil, tetapi juga dalam jumlah yang sangat besar. Masyarakat dapat membeli mobil, buku, tiket pesawat, property dan banyak lagi memakai transaksi melalui internet. Masyarakat dapat pula berbangga dengan informasi yang disediakan melalui sarana komputer, semua transaksi komersil ini disebut sebagai E-commerce.

Salah satu fasilitas yang berhubungan dengan komputer adalah internet, dimana internet berfungsi sebagai sarana komunikasi yang dilakukan melalui komputer, setiap orang dimana dan kapan saja dapat mengakses komputer.Untuk mendapatkan informasi yang mereka inginkan, baik untuk dunia usaha, pendidikan maupun hiburan.

Internet adalah jaringan komputer yang terdiri atas jaringan-jaringan komputer yang tersebar saat ini yang berisi informasi berupa gambar, animasi, suara dan video yaitu sebagai alat media komunikasi yang dapat 
diakses untuk mendapatkan dan memberikan informasi. Selain itu fungsi internet tidak hanya terbatas pada memberikan dan mendapatkan informasi, tepat juga untuk melakukan transaksi-transaksi dalam dunia usaha, sehingga suatu transaksi dapat dilakukan dalam subjek yang berjauhan tempat dan dalam waktu yang singkat.

Kini internet sudah menjadi permasalahan khusus semenjak dimanfaatkan dalam kegiatan perdagangan atau bisnis yang dikenal dengan transaksi $E$ commerce.Transaksi ini diakui secara ekonomi, oleh sebab itu pemanfaatan internet ini sangat riskan bagi para pihak karena karakteristiknya sangat berbeda dengan bisnis konvensional sehingga sulit dijangkau oleh aturan-aturan hukum yang berlaku.

Alasan ini berdasarkan pada suatu realitas bahwa transaksi E-commerce yang memanfaatkan media internet sifatnya tidak hanya sebatas lingkup local taupun nasional tetapi aktivitas transaksi E-commerce sudah berjalan tanpa batas (borderless word). Dalam kajian hukum ini memunculkan persoalan choice of law, choice of law forum, dan masalah yuridiksi. Namun demikian, bukan berarti karena ada kendala semacam ini, hukum tidak patut untuk mengaturnya, justru hal ini merupakan tantangan tersendiri, bagaimana hukum mampu memfasilitasi perkembangan tersebut. Proyeksi semacam ini adalah menggali masalah-masalah hukum yang sifatnya ius contituendum kemudian diformulasikan dalam konsep ius contitutum.

Masyarakat Indonesia belakangan ini mulai menyadari arti pentingnya sebuah asuransi dalam kehidupan mereka, tetapi kebanyakan dari mereka terlalu merasa malas merepotkan diri datang keperusahaan asuransi untuk mendapatkan informasi yang mereka butuhkan tentang asuransi tersebut. Dalam hal ini beberapa perusahaan asuransi telah melakukan sebuah terobosan untuk mempermudah calaon klien mereka yaitu dengan cara membuat home page mengenai perusahaan mereka, yang berisi tentang perusahaan tersebut, baik produk-produk dan kelebihan-kelebihan yang dimiliki dari perusahaan asuransi yang lainnya. ${ }^{1}$

Hal ini sangat mempermudah calon klien untuk mendapatkan informasi mengenai asuransi yang akan dibutuhkan klien, Karena atau tanpa harus datang kekantor atau perusahaan asuransi, calon klien tersebut sudah dapat mencari dan mendapatkan informasi sendiri melalui internet mengeni asuransi mana yang dibutuhakan calon klien.

"Perusahaan asuransi secara privat ekonomis dalam banyak hal jauh mempunyai arti yang amat besar dan dalam banyak hal keadaanya atau tidak kehadirannya juga menyangkut kepentingan sosial ekonomi, sebab perusahaan asuransi secara lansung

${ }^{1}$ Abdulkadir Muhammad, Hukum Asuransi Indonesia, Citra Aditya Bakti, Bandung, 2006, hlm. 1. atau tidak langsung, mempunyai peranan yang cukup besar dalam kegiatan sosial ekonomi".

Perusahaan asuransi tidak hanya menawarkan kemudahan dalam mendapatkan informasi tentang perusahaan asuransi tetapi juga kemudahan dalam melakukan penutupan asuransi, dimana calon tertanggung dapat mengisi formulir pendaftaran dan dapat langsung melakukan penutupan asuransi, dimana calon tertanggung dapat mengisi formulir pendaftaran dan dapat langsung melakukan penutupan asuransi melalui internet, yang kemudian akan Follow up oleh perusahaan asuransi tersebut. Fasilitas memberikan solusi baru dalam dunia asuransi tersebut maka proses penutupan asuransi tersebut dapat dilakukan tanpa kedua belah pihak bertemu terlebih dahulu.

"Perusahaan asuransi sebagai suatu lembaga mempunyai fungsi sebagai suatu lembaga yang menyediakan diri untuk dalam keadaan tertentu memerima risiko pihak-pihak lain, khusus risiko-risiko ekonomi dengan mekanisme kerja padanya, setiap kemungkinan menderita kerugian dapat dengan tepat dan cepat diatasi".

Secara umum syarat sahnya perjanjian asuransi atau pertanggungan diatur dalam Pasal $1320 \mathrm{KUH}$ Perdata, dan secara khusus di atur dalam KUHD. Menurut Pasal 1320 KUH Perdata bahwa ada empat syarat yang harus dipenuhi untuk sahnya suatu perjanjian, yaitu sebagai berikut :

1) Sepakat mereka yang mengikatkan dirinya;

2) Kecakapan untuk membuat suatu perikatan;

3) Suatu hal tertentu;

4) Suatu sebab yang halal.

\section{Ad.1. Sepakat mereka yang mengikatkan dirinya}

Syarat pertama merupakan awal dari terbentuknya perjanjian yaitu adanya kesepakatan antara pihak (penanggung dan tertanggung) tentang isi perjanjian asuransi yang akan mereka laksanakan. Timbulnya kata sepakat tidak boleh disebabkan oleh tiga hal, yaitu adanya unsur paksaan, penipuan, dan kekeliruan (Pasal 1322 KUH Perdata). Apabila perjanjian tersebut dibuat berdasarkan adanya paksaan dari salah satu pihak, maka perjanjian tersebut dapat batalkan. ${ }^{3}$

\section{Ad.2. Kecakapan untuk membuat perikatan}

Pada saat penyusunan kontrak, para pihak secara hukum telah dewasa atau cakap berbuat atau belum dewasa tetapi ada walinya. Didalam KUH Perdata yang disebut sebagai pihak yang tidak cakap untuk membuat suatu perjanjian adalah orang-orang yang belum dewasa

${ }^{2}$ Sri Rejeki Hartono, Hukum Asuransi dan Perusahaan Asuransi, Sinar Grafika, Semarang, 1991, h. 10-11

3 Kornelius Simanjuntak, Myra R.B. Setiawan, dan Brian Amy Prasetyo, Hukum Asuransi ,Djokosoetono Research Center, Depok, 2011, hlm. 13 
dan mereka yang dibawah pengampuan. Jika tidak dibawa pengampuan, maka berarti tidak dibawah pengampuan. Jika belum dewasa ia dibawah perwalian, jadi yang bertindak adalah walinya.

\section{Ad.3. Mengenai suatu hal tertentu}

Secara yuridis suatu perjanjian harus mengenal hal tertentu yang telah disetujui. Suatu hal tertentu disini adalah objek perjanjian asuransi. Suatu perjanjian harus memiliki objek tertentu, jelas dan tegas. Tertanggung harus mempunyai hubungan langsung dengan objek atau benda pertanggungan. Hal ini harus dapat dibuktikan oleh tertanggung bahwa tertanggung benar-benar memiliki dan mempunyai kepentingan terhadap benda yang dipertanggungkan.

\section{Ad.4. Suatu sebab yang halal}

Setiap perjanjian yang dibuat oleh para pihak tidak boleh bertentangan dengan Undang-undang, ketertiban umum dan kesusilaan, sesuai dengan Pasal 1337 KUH Perdata.

Menurut Pasal 1338 KUH Perdata menyebutkan bahwa "Suatu persetujuan yang dibuat sesuai dengan Undang-undang yang berlaku sebagai undang-undang bagi mereka yang membuatnya". Pasal ini lazimnya disebut asas kebebasan berkontrak.

Penutupan perjanjian melalui media internet yang dilakukan tanpa hadirnya kedua belah pihak menimbulkan banyak pertanyaan dibenak masyarakat.Apakah hal tersebut dapat dilakukan dan apakah perjanjian asuransi tersebut berbeda dengan asuransi yang dilakukan secara konvensional.

\section{METODE}

Menurut Peter Mahmud Marzuki, penelitian hukum adalah suatu proses untuk menemukan aturan hukum, prinsip-prinsip hukum, maupun doktrin-doktrin hukum guna menjawab isu hukum yang dihadapi. Penelitian hukum normatif, hukum dikonsepkan sebagai apa yang tertulis dalam peraturan perundang-undangan (law in a book) atau hukum dikonsepkan sebagai kaidah atau norma yang merupakan patokan berperilaku manusia yang dianggap pantas. ${ }^{4}$

Penelitian yang digunakan dalam penulisan ini yaitu penelitian normatif yakni penelitian hukum yang dilaksanakan menggunakan teknik meneliti bahan pustaka yang memakai objek penulisan berupa pustakapustaka yang ada, baik berbentuk buku-buku, majalah, serta ketetapan-ketetapan yang memiliki hubungan dengan pembahasan skripsi ini, alhasil penulisan ini sifatnya juga penulisan pustaka (library research) ${ }^{5}$

\footnotetext{
${ }^{4}$ Peter Mahmud Marzuki. Penelitian Hukum. Jakarta: Kencana Prenada Media Group. 2009. hlm.93

5 Soerjono Soekanto. Penelitian Hukum Normatif. Jakarta: Rajawali Press. 1998. hlm.15.
}

\section{HASIL DAN PEMBAHASAN}

Asuransi atau pertanggungan merupakan terjemahan dari insurance atau assurance yang timbul karena kebutuhan manusia. Manusia selalu dihadapkan kepada sesuatu hal yang belum pasti yang mungkin menguntungkan, tetapi mungkin juga sebaliknya apabila peristiwa tidak pasti tersebut terjadi dan meguntungkan atau menyenangkan, akan merupakan suatu keuntungan yang tentu diharapkan. Sedangkan apabila peristiwa yang tidak pasti terjadi tersebut menimbulkan kerugian maka kemungkinan menderita kerugian dimaksud disebut dengan risiko.

Lembaga Asuransi merupakan salah satu organ masyarakat, oleh karena itu setiap lembaga tidak mungkin berdiri sendiri, dan sebagai organ masyarakat, maka lembaga itu ada dan berada didalam masyarakat. Karena suatu lembaga tidak mungkin dapat berdiri sendiri, maka suatu lembaga juga tidak mungkin merupakan tujuan terakhir.

Perusahaan asuransi secara terbuka menawarkan suatu proteksi atau perlindungan dan harapan pada masa yang akan datang, baik kepada kelompok maupun perorangan atau perusahaan-perusahaan lain atas kemungkinan menderita kerugian lebih lanjut atas adanya suatu risiko.

Lembaga asuransi sebagai saran pemindahan risiko dari pihak yang ingin mengalami kerugian dan tidak ingin menanggung risiko itu sendiri, namun tidak semua risiko dapat diasuransikan. ${ }^{6}$

Asuransi yang paling ideal adalah asuransi yang risiko kerugiannya besar, namun probalitasnya rendah.Kerugian besar itu penting bagi tertanggung.Sedangkan probalitas yang rendah memungkinkan premi yang relatif kecil dibandingkan dengan kemungkinan-kemungkinan itu.

Apabila telah memenuhi syarat-syarat seperti disebutkn diatas, maka pihak tertanggung dapat mengasuransikan barangnya.Untuk mengasuransikan barang tersebut, tertanggung harus melakukan suatu perjanjian dengan pihak penaggung.

Jika dilihat dari bentuk perjanjiannya, maka perjanjian asuransi merupakan salah saat perjanjian khusus yang diatur dalam Kitab Undang-undang Hukum Dagang.Pada umumnya suatu syarat perjanjian haruslah memenuhi syarat-syarat yang tertuang didalam Kitab Undang-undang Hukum Perdata maka syarat tersebut

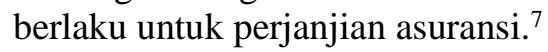

Menurut Pasal 251 Kitab Undang-undang Hukum Dagang, semua pemberitahuan yang salah atau tidak benar, atas penyembunyian keadaan yang telah diketahui tertanggung tentang asuransi, mengakibatkan asuransi

6 Kapler Marpaung, Meminimalkan Konflik Dalam Proses Klaim Asuransi ,Jurnal Asuransi, Jakarta, 2007, hlm. 5.

${ }^{7}$ H.M.N. Purwosutjipto, Pengertian Pokok Hukum Dagang Indonesia : Hukum Pertanggungan, Djambatan, Jakarta, 1990, hlm.47. 
itu batal. Artinya, tertanggung wajib memberitahukan kepada penaggung mengenai objek keberadaan asuransi. Kewajiban tersebut dilakukan oleh tertanggung pada saat mengadakan asuransi, dan apabila tertanggung lalai, keliru dalam memberitahukan, tanpa kesengajaan maka akibat hukumya asuransi itu batal, kecuali jika tertanggung dan penanggung telah memperjanjikan hal lain.

Bahwa untuk dapat disebut perjanjian asuransi maka ada beberapa unsur yang harus dipenuhi yaitu :

1. Adanya penaggung dan tertanggung sebagai para pihak.

2. Adanya premi, yaitu sejumlah uang yang harus dibayar tertanggung kepada penanggung.

3. Adanya peristiwa tertentu yaitu peristiwa yang belum terjadi.

4. Adanya ganti rugi, istilah ganti rugi hanya dikenal dalam asuransi kerugian sebab dalam asuransi jiwa tidak dikenal istilah ganti rugi, karena menyangkut nyawa seseorang dan hilangnya nyawa seseorang tidak dianggap sebagai satu kerugian.

Selain syarat-ssyarat perjanjian asuransi tersebut, perjanjian asuransi jauga harus memenuhi asas-asas dalam Buku I Bab IX Kitab Undang-undang Hukum Dagang yakni:

1. Asas Idemnitas (Principle Of Indemnity)

2. Asas Kepentingan (Principle Of Insurable Interset)

3. Asas Kejujuran yang Sempurna (Ut Most Good Faith)

4. Asas Subrogasi Pada Penanggung.

\section{Prinsip Idemnitas (Principle Of Indemnity)}

Prinsip atau asas idemnitas adalah suatu asas utama dalam perjanjian asuransi, karena asas ini mendasari mekanisme kerja dan memberikan arah tujuan dari perjanjian asuransi. Perjanjian asuransi bertujuan utama dan spesifik ialah untuk memberikan ganti kerugian kepada pihak tertanggung oleh pihak penanggung. Asas ini dapat dijumpai dalam ketentuan Pasal 246 KUHD yaitu Seorang penanggung mengikatkan diri kepada seseorang tertanggung dengan menerima suatu premi, untuk memberikan penggantian kepadanya karena suatu kerugian, kerusakan atau kehilangan keuntungan yang diharapkan. Dalam asas idemnitas ini terkandung dua aspek, yaitu :

1. Aspek berhubungan dengan perjanjian tujuan perjanjian

Aspek ini harus ditujukan kepada ganti-kerugian yang tidak boleh diarahkan bahwa pihak tertanggung karena pembayaran ganti-rugi menduduki posisi yang lebih menguntungkan. Hal ini berarti terdapat klausula yang bertentangan dengan tujuan ini menyebabkan batalnya perjanjian.

2. Aspek yang berhubungan dengan pelaksanaan perjanjian asuransi sebagai keseluruhan yang sah, dan aspek ini tidak boleh bertentangan dengan aspek yang lama.

\section{Prinsip Kepentingan (Principle Of Insurable Interset)}

Setiap pihak yang mengadakan perjanjian asuransi harus mempunyai kepentingan. Kepentingan yang dimaksud adalah kepentingan yang dapat diasuransikan, maksudnya bahwa pihak tertanggung mempunyai keterlibatan sedemikian rupa dengan akibat dari peristiwa yang belum pasti terjadi dan yang bersangkutan menjadi menderita kerugian Pengertian kepentingan dalam perjanjian asuransi atau pertanggungan adalah apabila Orang tersebut dapat menderia kerugian.

\section{Asas Kejujuran Yang Sempurna (Ut Most Good Faith)}

Asas kejujuran merupakan asas semua perjanjian yang harus dimiliki oleh setiap pihak yang akan mengadakan perjanjian. Isilah kejujuran lazimnya juga dikenal dengan isilah principle of utmose good faith atau uberrimae. Tidak terpenuhinya asas ini pada saat penutupan perjanjian, maka perjanjian tersebut cacat kehendak sebagaimana diatur dalam ketentuan-ketentuan KUH Perdata Pasal 1320-1329 dan pasal 1338 KUH perdata tentang asas kebebasan berkontrak. Demikian juga halnya dengan perjanjian asuransi, asas ini merupakan asas utama, karena apabila asas ini tidak diperhatikan akan merugikan salah satu pihak. Dalam Pasal 251 KUHD disebutkan bahwa setiap keterangan yang keliru atau tidak benar, ataupun tidak memberitahukan hal-hal yang diketahui oleh sitertanggung, betapapun itikad baik ada padanya, yang dimikian sifatnya sehingga seandainya penanggung telah mengetahui keaadan yang sebenarnya, perjanjian itu tidak akan ditutup atau tidak ditutup dengan syaratsyarat yang sama, mengakibakan batalnya pertanggungan.

\section{Asas Subrogasi Pada Penanggung}

Sebagaimana dijelaskan diatas, pada prinsipnya tujuan perjanjian asuransi adalah unuk memberikan ganti kerugian yang diderita oleh sitertanggung, sebagai landasan atau dasar ganti kerugian tersebut adalah asas subrogasi. Subrogasi dapat terjadi dengan baik apabila dengan persetujuan atau perjanjian maupun demi undang-undang. Subrogasi di dalam asuransi adalah subrogasi berdasarkan undang-undang.

Asas subrogasi dapat ditegakkan, apabila hak tersebut timbul karena terjadinya suatu kerugian dan apabila tertanggung disamping mempunyai hak terhadap penanggung masih mempunyai hak terhadap penanggung.

Dari uraian pengerian prisip-prinsip asuransi diatas maka dapat diketahui prisip-prinsip asuransi diatas berujuan sebagai pedoman untuk melaksanakan perjanjian asuransi dan juga prinsip-prinsip asuransi di 
atas bertujuan untuk mencegah atau menanggulangi risiko-risiko yang mungkin akan terjadi.

Ada beberapa sifat dalam perjanjian asuransi, yakni : 8

(1) Kontrak asuransi merupakan aleatory contracts, yaitu dalam perjanjian, jumlah yang dibayarkan tidak sama besarnya dengan jumlah uang yang akan diterima.

(2) Dalam pertanggungan tidak ada tawar-menawar untuk membuat perjanjian itu (contract of adhesion). Kontrak yang disusun perusahaan asuransi, dimana kita menerima kontrak tersebut.

(3) Perjanjian asuransi merupakan kontrak unilateral (unilateral contract), artinya perjanjian berlaku secara unilateral, jika tertanggung sudah membayar premi, perusahaan asuransi harus melunasi ganti kerugian atu apa yang telah di janjikan.

(4) Meskipun perusahaan asuransi telah berjanjian untuk membayar ganti rugi, maka tertanggung harus memenuhi syarat-syarat (kondisi) yaitu, misalnya saja jika terjadi kerugian dikatakan dalam kontrak bahwa dalam waktu satu hari harus memberitahukan kepada perusahaan asuransi.

(5) Kontrak harus dibuat secara jujur.

(6) Perjanjian asuransi merupakan "contract of idemnity" yang artinya kita tidak boleh mencari keuntungan dalam kontrak asuransi. Oleh karena itu adanya doktrin ini timbulah apa yang dinamakan :

(a) Doctrine of insurable interest, yang artinya bila benar0benar terjadi kerugian, terhadap milik yang dipertanggungkan itu.

(b) Doctrine of limitation of recovery, artinya ada jumlah tertentu atau jumlah maksimum yang bisa diberikan kepada seseorang (pengganti kerugian).

(c) Doctrine of subrogation, arti subrogasi hak untuk menaggi terhadap pihak ketiga.

(7) Warranty, ialah suatu jaminan apa yang telah dijanjikan pada masa sekrang dan betul-betul dipenuhi pada waktu yang akan datang.

(8) Ambiguty, yang berarti bila mana terjadi perselisihan antara perusahaan asuransi dengan tertanggung, maka hakim akan membenarkan si tertanggung, sebab pembeli asuransi tidak menguasai persoalan dalam asuransi.

Asuransi kerugian mempunyai ciri-ciri lain, kepentingannya dapat dinilai dengan uang (material) dan dalam menetukan ganti kerugian berlaku asas idemnitas, serta berlaku ketentuan-ketentuan subrogasi.

Polis asuransi merupakan suatu statement yang dibuat oleh tertanggung, didalamnya juga dimasukkan

8 Yusuf Shofie, Perlindungan Konsumen dan Instrumen-instrumen Hukumnya, Citra Aditya Bakti, Bandung, 2003, hlm. 179 hal-hal yang dikecualikan, dan syarat-syarat apa saja yang harus dipenuhi.

Pada dasarnya polis terdiri dari 4 (empat) bagian, yaitu :

a. Deklarasi

Deklarasi merupakan pernyataan yang dibuat oleh calon tertanggung, yang pada dasarnya memberikan keterangan mengenai beberapa hak, baik mengenai jati dirinya maupun mengenai barang yang dipertanggungkan. Didalam deklarasi ini memuat antara lain :

1) Identitas, dan alamat;

2) Nilai barang yang bersangkutan;

3) Keterangan lengkap mengenai barang yang bersangkutan;

4) Waktu yang diminta;

5) Dan sebagainya.

b. Klausula Pertanggungan

Klausula pertanggungan merupakan bagian yang utama dari suatu polis. Pada bagian klausula ini dengan jelas dianut ketentuan mengenai risiko apa saja dari polis yang bersangkutan, yang ditanggung oleh penaggung, syarat-syarat yang diminta dan ruang lingkup tanggung jawab penanggung.

c. Pengeculaian-pengecualian

Polis ini menentukan terhadap hal-hal apa saja terdapat pengecualian, apakah bencana atau bahaya, ataukah mengenai kerugian-kerugian tertentu dikecualikan dalam perjanjian yang dimaksud.

d. Kondisi-kondisi

Dalam polis ini dijelaskan tentang apa yang menjadi hak dan kewajiban para pihak, baik pihak penanggung dan pihak tertanggung. Kondisi-kondisi tersebut biasanya mengenai :

1) Pembayaran premi;

2) Pertanggungan-pertanggungan lain;

3) Perubahan risiko;

4) Kewajiban tertanggung bila terjadi peristiwa;

5) Laporan kerugian;

6) Ganti rugi;

7) Kerugian atas barang;

8) Ganti rugi pertanggungan rangkap;

9) Pertanggunag dibawah harga;

10) Laporan palsu;

11) Taksiran harga dalam kerugian;

12) Biaya yang diganti;

13) Pembayaran ganti rugi;

14) Sisa barang;

15) Sisa jumlah pertanggungan;

16) Subrogasi;

17) Gugurnya hak ganti rugi;

18) Penghentian pertanggungan;

19) Pengembalian premi;

20) Perselisihan

21) Penutup. 
Khusus untuk risiko yang dijamin, dalam penulisan polis pada dasarnya terdapat dua cara pendekatan. Yang pertama adalah pendekatan secara peril (peril approach), sedangkan yang kedua adalah pendekatan secara all-risk (all risk approach).

Untuk melakukan perjanjian asuransi biasanya para pihak yang akan membuat kesepakatan tersebut harus bertemu secara langsung. Namun, seiring dengan berkembangnya teknologi, maka para pihak dalapat melakukanya melalui suatu media yaitu internet.

Melalui internet, kita dapat melakukan berbagai macam hal, mulai dari membeli barang, mendapatkan informasi, melakukan suatu perjanjian dan sebagainya. Seperti halnya berbelanja di internet, perjanjian asuransi juga dapat dilakukan oleh pihak tertanggung dengan pihak penganggung dengan menggunakan media internet, dimana keduanya tidak bertmu secara langsung.

Sama halnya dengan perjanjian asuransi konvensional, calon tertanggung harus melaui beberapa proses perjanjian asuransi. Pada penutupan perjanjian asuransi kerugian secara online melaui media internt, calon tertanggung harus melalui beberapa proses. ${ }^{9}$

"Adapun proses penutupan asuransi kerugian melalui media internet yakni pada awalnya calon tertanggung yang ingin melakukan penutupan asuransi kerugian melalui media internet membuka website perusahaan asurasi yang di inginkan, kemudian setelah itu pada website perusahaan asuransi tersebut akan tertera transaksi online, bila kita tertarik untuk mengadakan penutupan asuransi, maka calon tertanggung tunggal mengklik (menekan tombol) Order Polis baru, kemudian akan ada formulir order polis baru yang harus di isi oleh calon tertanggung mengenai obyek asuransi. Jika sudah, maka untuk selanjutnya calon tertanggung mengklik kembali tombol next, setelah itu akan tertera tentang rincian premi yang harus dibayar oleh calon tertanggung, kemudian calon tertanggung mengklik next kembali, dilanjutklan dengan pengisian data oleh tertanggung, yang meliputi tempat tanggal lahir, alamat rumah, data pekerjaan, dan lain-lain. Apabila telah selesai maka pihak asuransi akan membuat kesepakatan dengan menetukan jadwal survey sebelum penerbitan polis, setelah itu klik next kembali, dan akan tersedia form mengenai sistem pembayaran, apakah melalui kredit atau transfer, jika sudah ada, maka klik next kembali dan ada halaman konfirmasi. Pada halaman konfirmasi tertanggung tinggal mengklik tombol next. Dengan mengklik tombol next tersebut calon tertanggung dianggap telah menyatakan menyetujui perjanjian tersebut sehingga transaksi perjanjian asuransi telah selesai".

${ }^{9}$ Wirjono Prodjodikoro, Hukum Asuransi di Indonesia, PT. Intermasa, Cet. Keempat, 1972, hlm. 15
Dalam perjanjian atau kontrak haruslah sesuai dengan ketentuan Pasal 1320 KUH. Perdata. Pada Pasal $1320 \mathrm{KUH}$. Perdata salah satu unsur perjanjian yakni kesepakatan. Kesepakatan merupakan syarat utama untuk terbentuknya suatu perjanjian, namun karena transaksi ini dilakukan melallui media elektronik dalam hal hal ini adalah internet, kesepakatan tersebut tidak diberikan secara langsung (tidak bertemunya para pihak dalam perjanjian). Untuk mengetahui kapan terjadinya kesepakatan melalui internet trsebut, maka terlebih dahulu dapat dilihat sistem yang berlaku pada transaksi jual beli di internet, Pada transaksi jual beli di internet terdapat tiga sistem yang berlaku, yang pertama calon pembeli melihat layar komputer adanya penawaran dari calon penjual (klik pertama), kedua si calon pembeli memberikan penerimaan terhadap penawaran tersebut (klik kedua),dan yang terakhir masih di isyaratkan adanya peneguhan dan persetujuan dari calon penjual kepada pembeli perihalnya diterimanya penerimaan dari calan pembeli dan klik ketiga. ${ }^{10}$

Mengenai kesepakatan dalam transaksi penutupan perjanjian asuransi kerugian melalui media internet maka pada saat calon tertanggung telah mengisi semua formulir yang telah disediakan dan menyetujui kesepakatan yang telah dibuat dengan mengklik tombol next pada halaman konfirmasi, maka kesepakatan dianggap telah terjadi.

Dari uraian tersebut diatas maka dapat kita ketahui bahwa apabila hanya dengan menggunakan media internet, penutupan perjanjian asuransi kerugian dapat dilakukan sesuai dengan prosedur yang ada.

Didalam asuransi kerugian, baik secara konvensional ataupun melalui internet, apabila terjadi klaim dari pihak tertanggung maka tanggung jawab penaggung akan sangat diperlukan.

"Perjanjian asuransi merupakan suatu perjanjian timbal balik (waderkerige evereekomst). Dlam arti bahwa suatu perjanjian asuransi, para pihak baik tertanggung maupun penanggung, masing-masing mempunyai hak dan kewajiban yang saling timbal balik. Antara tertanggung dan penanggung ada prestasi dan kontraprestasi satu dengan yang lain. Penanggung berdasarkan kondisi tertentu berjanji akan membayar atau membayar, atau memberikan jasa-jasa tertentu apabila tertanggung menderita kerugian yang mengakibatkan karena terjadinya peristiwa yang tidak tentu. Peristiwa yang tidak tentu itu merupakan suatu peristiwa yang menimbulkan kerugian yang datangnya dari luar dan tidak dapat diduga kapan terjadinya, dan tidak ada unsur

${ }^{10}$ Djoko Prakoso dan I Ketut Murtika, Hukum Asuransi Indonesia, Rineka Cipta, Jakarta, 2004. hlm. 59. 
kesengajaan. Sedangkan tertanggung berkewajiban untuk membayar premi kepada penanggung". ${ }^{11}$

Perusahaan asuransi sebagai pihak penaggung mempunyai tanggung jawab terhadap suatu barang milik tertanggung yang menjadi objek asuransi. Pada umumnya mengenai tanggung jawab yang berisikan janji-janji khusus penanggung telah dibuat polis yang lazim disebut klausula asuransi.

Maksud klausula asuransi tersebut adalah untuk mengetahui batas-batas tanggung jawab penaggung dalam pembayaran ganti kerugian apabila terjadi peristiwa yang mengalami kerugian.

Ada beberapa jenis klausula asuransi dan jenisjenis klausula tersebut ditentukan oleh sifat objek asuransi, bahaya yang mengancam dalam setiap asuransi. Klausula-klausula tersebut antara lain :

a. Klausula Premier Risque

Klausula ini biasa digunakan pada asuransi pembongkaran dan pencurian (burgary insurance), asuransi tanggung jawab (liability insurance). Klausula ini menyatakan bahwa apabila pada asuransi di bawah nilai benda terjadi kerugian sebagian, maka penanggung akan membayar ganti kerugian seluruhnya sampai maksimum jumlah yang diasuransikan (ketentuan Pasal 253 Ayat (3) Kitab Undang-undang Hukum Dagang.

b. Klausula All Risk

Klausula ini menentukan bahwa penaggung memikul segala risiko atas benda yang diasuransikan.

c. Klausula sudah diketahui (all seen)

Klausula ini digunakan pada asuransi kebakaran (fire insurance). Klausula ini menentukan bahwa penanggung sudah mengetahui betul keadaan, konstruksi, letak, dan cara pemakaian bangunan yang diasuransikan.

d. Klausula renunisasi (renunciation)

Klausula ini artinya pelepasan hak, klausula ini berhubungan dengan Pasal 251 KUHD yang berarti melepaskan hak gugat berdasarkan Pasal tersebut. Ini berarti apabila timbul kerugian baik evenemen bagi tertanggung, pada tertanggung tidak memberitahukan keadaan objek asuransi pada penanggung, maka penanggung tidak akan mengajukan alasan Pasal 251 KUHD (tidak akan memberitahukan keadaan objek asuransi), dan penanggung akan membayar klaim kerugian kepada tertanggung.

e. Klausula Free From Particular Averege (FPA)

Klausula ini digunakan pada asuransi pengangkutan laut. Averege artinya peristiwa kerugian laut.

Selain dibuat dalam klusula asuransi, secara umum didalam Pasal 290 KUHD dijelaskan secara umum tanggung jawab penanggung menyatakan

${ }^{11}$ Ferdinand Silalahi, Manajemen Risiko dan Asuransi, Raja Grafindo Persada, Jakarta, 2003, h. 543 tanggungan si penanggung adalah segala kerugian dan kerusakan yang menimpa benda yang dipertanggungkan karena kebakaran, yang disebabkan karena petir atau kecelakaan, api sendiri, kurang hati-hati, kesalahan atau itikad jahat dari pelayan-pelayan sendiri, tetangga, musuh, perampok, dan lain-lain dengan nama apa saja, dengan cara bagaimanapun kebakaran itu telah terjadi, disengaja atau tidak, biasa atau luar biasa, dengan tiada kecualinya. $^{12}$

Menurut Pasal 249 KUHD, ada tiga jenis pembatasan tanggung jawab penaggung terhadap asuransi, yaitu :

1) Kerugian yang timbul karena cacat sendiri (selfdefect) pada asuransi.

2) Kerugian yang timbul karean kebusukan sensiri (selfrot) pada benda asuransi.

3) Kerugian yang timbul karean sifat dan kodrat (natural character) pada benda asuransi.

Pembatasan mengenai kesalahan tertanggung sendiri diatur dalam Pasal 276 KUHD. Menurut ketentuan pasal tersebut tiada kerugian atau kerusakan yang disebabkan karena kesalahan si tertanggung sendiri harus ditanggung oleh si penanggung. Bahkan berhakah si penanggung memikul premi ataupun menuntutnya, apabila tertanggung sudah mulai memikul suatu bahaya.

Adapun yang diamaksud dengan kesalahan tertanggung sendiri adalah kesalahan karena tertanggung kurang hati-hati, kurang teliti, jadi bukan kesengajaan. Perbuatan kurang hati-hati dapat menimbulkan kerugian yang bukan menjadi tanggung jawab penanggung.

Selain pada tanggung jawab penggung terhadap objek asuransi seperti yang telah diuraikan diatas, penaggung juga harus bertanggung jawab untuk membyar ganti kerugian kepada tertanggung jika terjadi evenement. Evenement atau peristiwa yang tidak pasti adalah peristiwa yang menurut pengalaman manusia normal tidak dapat dipastikan terjadi, atau walaupunsudah pasti terjadinya itu tidak dapat ditentukan dan juga tidak diharapkan akan terjadi. Jika terjadi menimbulkan kerugian.

Dalam asuransi yang menjadi evenement yang menjadi beban penaggung merupakan bahaya yang mengancam keselamatan benda asuransi atau objek asuransi yang berupa jiwa atau raga manusia. Selama belum terjadi bahaya yang mengancam ini disebut risiko.

Asuransi sebagai alat peralihan risiko, artinya asuransi dapat dipakai sebagai salah satu wahana untuk mengadakan peralihan risiko. Risiko pihak yang satu (tertanggung) dialihkan kepada pihak lain (penanggung). Peralihannya dengan suatu perjanjian, yaitu perjanjian asuransi kedua belah pihak.

Untuk menentukan apakah penanggung bertanggung jawab terhadap suatu kerugian atau tidak,

12 Abdulkadir Muhammad, Hukum Asuransi Indonesia, Cetakan ke-4, PT Citra Aditya Bakti,Bandung: 2006, hlm. 2 
maka ada beberapa teori yang perlu kita ketahui,teori tersebut adalah sebagai berikut :

(a) Teori Causa Proxima

Menurut teori ini, maka hanya peristiwa secara kronologis mempunyai urutan terdekat kepada kerugian saja yang dapat dipertanggung jawabkan kepada penanggung.

(b) Teori conditio sine Quanon

Berdasarkan teori ini, maka yang dianggap sebagai peristiwa yang menimbulkan kerugian adalah setiap atau semua peristiwa yang mendahului terjadinya kerugian tersebut.

(c) Teori causa Remota

Teori ini menyatakan bahwa (peril) yang menyebabkan timbulnya kerugian adalah peristiwa yang paling jauh.

(d) Teori Adequate

Berdasarkan teori ini, maka peristiwa yang dianggap sebagai peristiwa yang menimbulkan kerugian adalah peristiwa yang berdasarkan pengalaman dianggap pantas menimbulkan kerugian tersebut. Jadi tidak perlu adanya hubungan yang tegas, yang diperlukan hanyalah suatu penilaian, yaitu apakah peristiwa itu pantas terjadi apabila suatu peristiwa tertentu lainnya terjadi.

"Menurut Widya tanggung jawab asuransi kerugian yang dilakukan secara online melalui internet ternyata tidak berbeda dengan tanggung jawab asuransi kerugian konvensional, artinya meskipun penutupan perjanjian asuransi dilakukan melalui internet, hal-hal yang menjadi pedoman untuk menentukan tanggung jawab penanggung terhadap tertanggung tetap menggunakan klausula-klausula asuransi konvensional. Karena baik secara konvensional maupun melalui internet yang membedakannya hanyalahmedia atau sarana yang digunakan, dan mengenai tanggung jawab biasanya telah tertuang dalam perjanjian asuransi".

Dari uraian tersebut diatas maka dapat kita ketahui bahwa tanggung jawab antara perusahaan asuransi (penanggung) terhadap tertanggung jika terjadi klaim kerugian dimana penutupan asuransinya melalui media internet, adalah sama halnya dengan tanggung jawab asuransi yang ditutup secara konvensional, dimana tanggung jawab perusahaan asuransi baik yang melalui internet maupun konvensioanal sudah ditegaskan dalam polis asuransi kerugian serta pengecualiannya yang telah disepakati oleh kedua belah pihak pada waktu penutupan perjanjian asuransi. ${ }^{13}$

\section{SIMPULAN}

Tanggung jawab antara perusahaan asuransi (penanggung) terhadap tertanggung jika terjadi klaim kerugian dimana penutupan asuransinya melalui media internet, adalah sama halnya dengan tanggung jawab asuransi yang ditutup secara konvensional, dimana tanggung jawab perusahaan asuransi baik yang melalui internet maupun konvensioanal sudah ditegaskan dalam polis asuransi kerugian serta pengecualiannya yang telah disepakati oleh kedua belah pihak pada waktu penutupan perjanjian asuransi.

\section{DAFTAR PUSTAKA}

Abdulkadir Muhammad, Hukum Asuransi Indonesia, Citra Aditya Bakti, Bandung, 2006

Djoko Prakoso dan I Ketut Murtika, Hukum Asuransi Indonesia, Rineka Cipta, Jakarta, 2004

Ferdinand Silalahi, Manajemen Risiko dan Asuransi, Raja Grafindo Persada, Jakarta, 2003

H.M.N. Purwosutjipto, Pengertian Pokok Hukum Dagang Indonesia : Hukum Pertanggungan, Djambatan, Jakarta, 1990

Kapler Marpaung, Meminimalkan Konflik Dalam Proses Klaim Asuransi ,Jurnal Asuransi, Jakarta, 2007

Kornelius Simanjuntak, Myra R.B. Setiawan, dan Brian Amy Prasetyo, Hukum Asuransi, Djokosoetono Research Center, Depok, 2011

Mulhadi, Dasar-dasar Hukum Asuransi, Cetakan ke-1, Rajawali Pers, Depok, 2017

Peter Mahmud Marzuki. Penelitian Hukum. Jakarta: Kencana Prenada Media Group. 2009

Soerjono Soekanto. Penelitian Hukum Normatif. Jakarta: Rajawali Press. 1998

Sri Rejeki Hartono, Hukum Asuransi dan Perusahaan Asuransi, Sinar Grafika, Semarang, 1991

Wirjono Prodjodikoro, Hukum Asuransi di Indonesia, PT. Intermasa, Cet. Keempat, 1972

Yusuf Shofie, Perlindungan Konsumen dan Instrumeninstrumen Hukumnya, Citra Aditya Bakti, Bandung, 2003 